ARTICLE

\title{
Publicising the News: Publicity and Australian Commercial Television News
}

\author{
MICHAELA JACKSON, RMIT UNIVERSITY
}

\begin{abstract}
In order for a democracy to be effective its citizens need to be adequately informed so they can make balanced and educated decisions about the way they are governed. However, the profit-driven motives of business can negatively impact the content of commercial television news. News today features more lighter news items - referred to by a number of terms such as 'soft', 'lifestyle' and 'snack' news (Plasser, 2005, p. 49). A simultaneous development has been the evolution of public relations and the subsequent increase in publicity material.
\end{abstract}

Established research indicates that liberal democracies like Australia have media practices that can negatively impact the public sphere and affect citizens' abilities to gather the information they need to make informed and balanced decisions. This research paper explores the extent to which Australian commercial television news is comprised of publicity material generated to enhance marketing agendas.

Content analysis was used to measure the prevalence of publicity in Australian commercial television news bulletins. A seven day sample of evening prime time bulletins from three Australian commercial television networks was recorded and analysed. Across all networks for the period 29 July to 4 August 2007, 994 publicity items were recorded across 474 news items. This averages 142 items across all networks per day and equates to just over two instances of publicity (in a variety of identified forms) per news story.

This research reveals a discrepancy between popular concepts of the role of news and its current presentation on commercial television. Traditional news models do not adequately cater for, or explain, this dual role. Central is the issue of the changing relationship between media practice and traditional notions of the role of media in democracy.

\section{KEYWORDS}

???

\section{INTRODUCTION}

In order for a democracy to be effective its citizens need to be adequately informed so they can make balanced and educated decisions about the way they are governed. As claimed by Kenneth Minogue 'democracy and the media has [sic] grown up together, and the media has taught many people the pleasures of having opinions on broad general subjects' (1997, p. 29). Today, the news features more lighter items - often referred to as 'soft', 'lifestyle' and 
'snack' news (Plasser, 2005, p. 49). A simultaneous development has been the evolution of public relations and the subsequent increase in publicity material.

As such, the question can to be asked: Is the role of news still to inform, or has it taken-on another role? Specifically, to what extent is news today actually comprised of publicity material generated to enhance marketing efforts?

In addition to the central research question, this research also explores the following issues:

- What is news?

- Why is news so important?

- What is publicity?

- Is the presence of publicity in Australian commercial television news necessarily a good or a bad thing?

- Why, as a society, are we placing these expectations on such a cultural form?

- What are the consequences of publicity on Australian commercial television news?

To date the vast majority of research with in this field has been conducted in the United States and, to a lesser extent, Europe. This paper addresses these research questions by reviewing existing literature in the field then applying content analysis methodology to a sample of news bulletins from Australian commercial television networks. By doing, so this research explores the relationship between commercial television news and publicity within an Australian context.

\section{LITERATURE REVIEW}

\section{WHAT IS NEWS?}

For such a frequently used word, I found it surprisingly difficult to find a consistent and concise definition for the term 'news'.

Marian Hudson accurately claims that 'there is no hard and fast definition of what comprises news' (1994, p. 11). However, after analysing the many definitions encountered, it appears that news can be broadly divided into three categories.

The simplest definitions classify news as private and informal - news that occurs between friends, colleagues or family. John Sommerville's definition typifies this category, explaining that 'unofficially, the news just means things that you want to hear about and tell others about' (1999, p. 11).

The second type - news that is public - is of greater interest and is readily available to a large number of people through public or established channels. John McManus simply describes the news as 'what the public does not yet know' (1992, p. 793). Somerville evolves his earlier definition by specifically placing news within a public context - the understanding that news is public is implicit in his mention of the market. According to this author news is not only 'what got into today's paper or broadcast' but what 'publishers think they can get us interested in and get ask to pay for' $(1999$, p. 12). In addition to referring to news as a commodity, Robert Goldman and Arvind Rajagopal also acknowledge the conventions and processes inherent in news, explaining that while news is characterised by a continual stream of new facts its underlying frameworks and formats remain constant (1991, p. 17). 
Ian Marshall and Damien Kingsbury's definition reflects the traditional and evolving aspects of news, the expectations and demands of both producers and consumers, and the importance of the news in helping members of a society construct their understanding of reality. They provide the following six part definition in support of this:

- News is a generic term covering informational, event-driven, mediated, managed, mediacoloured, and media-dominated content.

- Such content may cover spontaneously occurring or created events.

- News is generally presented in contexts of audience demand for novelty, urgency and universality.

- Its production involves both subjective judgments in selection and processing by editors and journalists, and the existence of organisational, technical and legal restraints.

- News production frequently involves both the construction (by external sources) and conversation (by media people).

- All of such elements involve reality construction in one sense or another. (Marshall and Kingsbury,1996, p. 42).

The distinction between hard and soft news appears both clear and consistent. Hard news refers to news that focuses on the facts, with minimal comment, and usually pertains to serious events (Hudson, 1994, p. 18). According to Herbert Gans, hard news relates mostly to news, such as political news, that citizens need to fulfil their democratic responsibilities. Put most simply, soft news is what's left. It covers a broad range of topics such as human interest stories, celebrity gossip, scandal, and entertainment (Gans, 2003, p. 28).

Interestingly, concepts such as impartiality, objectivity and honestly - all frequently encountered when discussing the role of journalists or journalism - were not explicitly mentioned in the definitions encountered.

\section{WHY IS NEWS IMPORTANT?}

Mass media helps us form our views and construct our reality on a broad range of subjects. As stated by Philo Wasburn 'mass media in democratic states offers a vigorous 'marketplace of ideas' that stimulates the public's political interest and makes available the specific information it needs to hold government accountable" (1995, p. 647). News receivers inherently place a large degree of trust in those who select and present us with this information. In order for views to be a true mirror of reality news producers who gather and deliver news items must do so in the form of a 'disinterested observer' (Goldman and Rajagopal, 1991, p. 9).

The fact that the majority of news services operate as commercial enterprises, seeking to maximise profits and returns for their shareholders, complicates this role. McManus claims that advantages offered by the market 'should apply particularly well to commercially produced news' $(1994$, p. 5). As with other commodities, in a competitive market situation consumers will logically offer their loyalty to those firms providing the highest quality news product (McManus, 1994, p. 5). But business values may not always automatically support journalistic ideals of public enlightenment (McManus, 1994, p. 24).

Some argue that news, as a product of the mass media, is a tool of control. Critical theorists 'view the mass media as means by which the haves of society gain the willing support of the have-nots to maintain the status quo' (Griffin, 1994, p. 344). Robert Connell maintains that the principles and sentiments that press proprietors support are those same principles, which 
'justify the social-economic system under which press proprietors and their friends flourish' (1977, p. 192). These 'vested interests' potentially erode the ability of news to arouse 'the public's political interest and makes available the specific information it needs to hold government accountable' (Wasburn, (1995, P. 647).

The role of news is closely related to the concepts of the public sphere and public opinion. Jeurgen Habermas explains that the public sphere didn't exist until the era of early market economics (1989, p. 7-15). Under a European feudal system the reining monarch made all decisions and effectively owned all within their kingdom (ibid). The decline of the feudal system and simultaneous development of trade and market economics brought about the early public sphere (ibid). For the first time the average person could make up their own mind, could earn their own money, and experience personal ownership. Those in power had to be aware of what the public thought. As expressed by Habermas, 'civic society came into existence as a corollary of a depersonalised state authority' (p. 19).

Habermas appears to suggest, albeit implicitly, an ideal point of balance that links the functioning of the public sphere to the development and growth of market economics. Accordingly, Habermas argues that the public sphere was at its best during a brief period between 1680 and 1730. However, Habermas later retracted this argument and scholars now generally disagree with this claim (McKee, 2005, p. 26).

As market economics have continued to develop and grow it appears that now there is too much emphasis on the market - constraining the optimal operation of the public sphere. Habermas claims that under a properly functioning system of market economics 'no one was expected to be able to gain so much power as to gain a position that gave him complete control over someone else' (Habermas, 1989, p. 144). The result is a society where the facilitators of the public sphere, the mass media, are more interested in pursuing their own interests than facilitating discussion among citizens (Habermas, 1989, p. 171).

But where modernists like Habermas see 'the degradation of a pre-existing bourgeois public sphere by the forces of consumer capitalism', postmodernists see the 'emergence of different publics, public spheres and public spaces, each with their own forms of communicative organization' (Dahlgren, p. 16). Fragmentation and trivialisation, concepts that the mass media is often criticised over are seen as positives by postmodernists. Alan McKee argues that changes such as this to the public sphere not only draw a wider range of issues to public attention, but also makes it simpler for people from a variety of backgrounds to access the public sphere, or spheres (p. 19). Postmodernists argue that the news, among other forms in the public sphere, is not so much being 'dumbed down' as made more accessible (McKee, p. 67).

\section{TELEVISION AS A NEWS MEDIUM}

Since its introduction to Australia in 1956, television has become 'our most used and trusted source of news' (Tiffen, 1989, p. 40). John Henningham explains that television was viewed as delivering:

- The most complete news and the most intelligent presentation

- Doing the most for the public

- Giving the clearest understanding of issues

- The best understanding of leaders (1988, p.1). 
Perhaps this is because television enabled information to be communicated through not just textual means but through audio and visual cues. However, the widespread popularity and trust of television news has raised questions about the quality of it as a news medium (Henningham, 1988, p. 13).

Television news producers skew content in favour of those stories or events with a strong visual element (Marshall and Kingsbury, 1996, P60). As a consequence, people who rely on television as their main way of receiving news may be 'misled into thinking that only what is interesting to watch is newsworthy' (McManus, 1994, p. 172). Further, the medium may be exploited by journalists, news directors or public relations practitioners to make sensational or controversial announcements they do not want rewritten or interpreted (Hudson, 1994, p. $51)$.

The nightly news bulletin is used to double effect by broadcasters: it assists in meeting local content quotas and helps to set up the evening's viewing schedule for audiences. Larger audiences translate to greater ratings, which in turn attract more advertisers at higher advertising rates. According to Henningham, 'an entertainment factor was consciously injected into television news' underlying which was 'the commercial imperative of ratings' (1988, p. 14).

\section{NEWS AS BUSINESS}

The relationship between democracy and capitalism has long been tense (Dahlgren, p. 1). In Australia, and other Western liberal democracies, the majority of television news services are provided by commercial networks. However, as raised by McManus, 'no comprehensive model of news production has included the concept of markets' (1994, p. 21). McManus even goes so far as to claim that the term 'market journalism' is largely an oxymoron (1994, p. 197).

As with all businesses the quest for profit maximisation rests on a simple equation of decreasing costs and increasing revenue. The challenge then becomes how to gain the attention of the maximum number of people, the largest audience, at the smallest cost. According to McManus, 'independent, particularly investigative, surveillance of a community is expensive' (1994, p. 88). Instead it is much more cost effective for commercial news enterprises to rely on cheaper options such as wire services, syndicated news, and press releases and agents (McManus, 1994, p. 88). Publicity plays a key role in providing potential news content, free, to media enterprises. Aeron Davis claims that in Britain, this rise in professional public relations can be linked to a corresponding drop in editorial resources of news producers (2000, p. 43).

Further problems arise through a market approach to news production. The first is the potential for bias towards advertisers. If a commercial television network has a significant amount of revenue derived from relatively few sources, it is in that network's best interest to ensure a favourable environment for their client (McManus, 1994, p. 78).

However not all television news providers are businesses. The Australian Broadcasting Corporation (ABC) was formed in 1932, and since this time has provided 'more news and current affairs to more people through radio, television, online and broadcast services than any other media organization in Australia' (ABC news and current affairs - accuracy and 
impartiality, 2005, p. 1). And it does so as a commercial free public broadcaster (All about the Australian Broadcasting Corporation, 2003, p. 2).

The ABC has developed editorial policies relating to non-commercial content and external funding. These detailed guidelines explain the organisation's approach to different forms of publicity and promotion. Their stance is summarised in reference 15.2.1 'The ABC is conscious that its audiences value the $\mathrm{ABC}$ 's role as a non-commercial broadcaster and its non-commercial style' (ABC Editorial Policies, 2007, p. 90). The ABC's ability to produce daily television news bulletins in accordance with these policy statements is testament to the fact that news which omits promotional content can be achieved within the broader context of a consumer society.

\section{WHAT IS PUBLICITY?}

This research focuses on publicity as an element of marketing public relations. However, it is important to understand the background and connections of both terms, as well as realising that often they work together.

Edward Bernays defines public relations as 'the attempt, by information, persuasion, and adjustment, to engineer public support for an activity, cause, movement or institution' (1955, p. 4-5). According to Bernays, public relations had three closely-related functions persuasion, information and adjustment $(1955$, p. 7). In more recent times Jo Samsup reports that 'public relations was primarily used to suggest image building, reputation management, and persuasion efforts' (2003, p. 397). While these two definitions are not inaccurate, I would argue that the most pertinent definition is provided by the Public Relations Institute of Australia (PRIA). It explains that 'public relations is the management function concerned with effective communication. It includes research to understand issues and public attitudes which have an impact on an organisation; planning and implementing communication activities to effect change; and evaluating outcomes' (About us, 2008).

Public relations can be used to pursue more specific goals - one of which is marketing (Harris $\&$ Whalen, 2006, p. v). In this sense, the two forms can be distinguished not so much by their tactics, but by their aims. While public relations generally may be concerned with goals such as managing reputation, building awareness and influencing attitudes, marketing public relations is more directly aligned to profit-oriented aims (Harris \& Whalen, 2006, p. 5, 8).

Public relations can be viewed as an element of the promotions mix - along with advertising, direct marketing, and personal selling - used in combination with other marketing strategies to develop, grow or sustain markets for a product, service or organisation. Thomas Harris and Patricia Whalen explain that while corporate public relations maintain the long-term health of the organization by building a strong corporate reputation, marketing public relations (MPR) focuses on just the product brand and its customers (Harris \& Whalen, 2006, p. 9-10). As such, the primary purpose of MPR is 'to achieve third-party endorsement from key customer influences such as the news media' (Harris \& Whalen, p. 9-10). Harris expands this definition to explain that marketing public relations is the process of planning, executing, and evaluating programs that encourage purchase and consumer satisfaction through credible communication of information and impressions that identify companies and their products with the needs, wants, concerns, and interests of consumers (Harris, 1998, p. 9-10).

Looking at definitions of publicity itself, there is much technical inaccuracy. Adding further 
complication are the proliferation of associated terms, such as 'hybrid messages', 'fake news', 'infotainment', 'newstainment', and 'hybrid promotional news'.

Popular definitions inaccurately compare publicity to 'unpaid advertising' or 'promotional material', both of which are technically non-viable or rhetorical definitions (Definitions of publicity on the web, n.d). Professional resources also prove confused. According to KnowThis.com the terms can be used interchangeably and refers to a type of promotion that 'uses third-party sources, and particularly the news media, to offer a favourable mention of the marketer's company or product without direct payment to the publisher of the information' (Principles of Marketing, n.d., p. 17).

Siva Balasubramanian does distinguish public relations from publicity and gives another partially-correct definition by claiming that 'publicity represents messages that are not paid for, and which do not identify the sponsor (Cohen 1998)' (Balasubramanian, 1994, p. 29).

In light of the above information I believe there are six characteristics that define publicity:

1. Secretive - As per Balasubramanian's definition, publicity is distinguishable from other forms of promotion in that it never explicitly reveals its client or sponsor.

2. Parasitic/ symbiotic - Publicity always depends on another media form to deliver its message to its target audience. This media is usually in the form of the news. As discussed below, this may take the form of either a detrimental or symbiotic relationship.

3. Free - Unlike most other promotional or professional communication tactics, there is no charge for a publicity story being run or aired.

4. Works to affect a positive outcome for its sponsor - Regardless of if the publicity is positive, defensive, or attacking in nature, it works to achieve a positive outcome for its client or sponsor.

5. Contextually adoptive - In doing so, publicity adopts, or tries to adopt, the format and identity of news items, which surround it.

6. A tactical element - Publicity is one part of a broader marketing or public relations campaign, which strategically support a broader product or organisationally-related objective. A publicity item is not a campaign in itself.

Publicity is most likely to manifest itself in the news industry as press or news releases either written, or in audio or video form - and often accompanied with images, video or audio footage, product shots, and excepts of interviews or quotes from carefully selected 'experts'. According to Hudson, the 'perfect' media release is one whereby a journalist repeats its content word for word (1994, p. 71).

\section{THE GROWTH OF PUBLICITY}

According to Simon Cottle, in recent decades public relations and publicity have come to 'play an increasingly important part in the reporting process' (2003, p. 27). With increased pressure for news producers to do 'more with less' it is little wonder that publicity has continued to become a stronger presence among news reports (Marshall and Kingsbury, 1996, p. 128). It makes business sense to reduce costly reporting resources and rely more heavily on pre-packaged, freely available material.

From a marketer's perspective, the benefits of publicity are many. Publicity is free and is associated with credibility that advertising literally cannot buy. As stated by Harris and Whalen 'it's easier for consumers to believe a message if it's coming from an independent 
third party than if you are shouting it in an ad' (2006, p. 4). According to Harris, publicity can be worth up to two or three times the advertising equivalent simply because messages appear in an editorial context (1998, p. 272).

Publicity can offer benefits to consumers as well, often containing information that is useful or interesting to an audience.

One of the main criticisms of publicity, particularly in regard to television news, is that the resulting commercial content takes the place of more valuable news being communicated (Erjavec, 2004, p. 573). Karmen Erjavec summarises general concerns about the commercialisation of journalism and its 'subordination to the business sphere and its logic of profit maximisation' (2004, p. 573).

An extension of the criticism looks at the power imbalances created as a result of publicity material being aired. Jerry Palmer claims that the rich in society have greater access to the media because they can afford to create 'information subsidies', publicity, and distribute them to the news media (2000, p. 53). Because publicity messages do not identify the sponsor, and hence appear more credible to an audience than advertisements, audiences tend to perceive the media as the legitimate source of any feature brand-related story (Balasubramanian, 1994, p. 29).

\section{THE QUALITY OF NEWS}

According to Fritz Plasser, 'few attempts have been made to define quality journalism in a form that makes it possible to measure the journalistic criteria of quality empirically' (2000, p. 51). One of the few studies to look specifically at this issue was conducted by Tom Rosensteil et al. They concluded that a quality television newscast 'should reflect its entire community, cover a broad range of topics, focus on the significant aspects of stories, be locally relevant, balance stories with multiple points of view, and use authoritative sources' (Rosensteil et al., 2000, p. 5).

Rostensteil et al. found that 'more than half all news stories (53 per cent) are either feeds from elsewhere or are covered with video but no reporter' $(2000, \mathrm{p}$. 4). Their study also found that the amount of investigative reporting is also in decline. These findings are consistent with Plasser's study, which documents the move towards soft news items concerning 'lifestyle, celebrity, entertainment, and celebrity/crime scandal' at the expense of coverage on government and foreign affairs issues (2005, p. 49).

The little available Australian research reveals similar trends. Mark Day, journalist for The Australian, wrote that 'the task of reporting our communities to ourselves is getting harder, yet many media companies are responding to declining readership and consequential falls in advertising revenue by cutting back on reporting numbers' (31 August, 2006). Day interviewed Peter Meakin, veteran news executive of the Nine Network, who attributed the change in news content to a desire among networks to make bulletins more relevant to audiences' lives, such as transport, the environment, health, and finance (Day, 3 August 2006), rather than to a decline in quality. 
The impacts of poor quality news are concerning. Democracy requires the media perform and provide a number of functions and services for the political system (Brants, 1998, p. 317). While it is unrealistic in a Western capitalist democracy to expect this responsibility to rest squarely with commercial media enterprises, do they at some point need to accept responsibility and balance between profits and public good?

Not all agree that the declining dominance of hard news is necessarily to the detriment of television news, or indeed society as a whole. According to Langer, this 'other news' is a legitimate form news that is essential in building a comprehensive understanding of broadcast journalism (1998, p. 1). From a practitioner's perspective, Hudson claims that a 'soft' style of news is at times needed - adding that factual information can need 'dressing-up' (1994, p. 18).

\section{RESEARCH METHODOLOGY}

Content analysis is an established research methodology within this field. It offers researchers a quantifiable way to address a research question and enables 'unobtrusive appraisal of television news programming' (Wood et al., 2004, p. 812). By analysing similar studies I have adapted previously used systems to develop a measurement system that is unique and appropriate to my research question.

I recorded and analysed the five or six o'clock nightly news broadcasts as seen on three commercial television stations in Melbourne (Channels Nine, Seven, and Ten) for a seven day period commencing late July 2007. All instances of publicity were recorded using a codification sheet and publicity diagnostic sheet (see Appendix A) based on the work of Erjavec, who analysed the increasing prevalence of promotional news - paid-for news items that are not identified as such to their audience (2004).

For the purposes of this study publicity is defined as unpaid promotional content that is positive in nature and that helps achieve an organisational goal. This type of material is also known by a variety of other names such as promotional news, advertorials, hybrid messages, masked news and fake news. This definition expands that developed by Michelle Wood et al. to emphasise the fact that publicity must be positive in nature (2004). Publicity by this definition may be further divided into the following sub-categories.

- Network cross promotion - a favourable or encouraging reference to a television programme on the same broadcast network.

- Promotion of the same news programme - a favourable or encouraging reference to the same news programme on the same broad cast network.

- Proprietor cross promotion - a favourable or encouraging reference to another product or service that is owned by the same proprietor or parent company as the news program.

- On-set product placement - a visual or verbal reference to a product or brand located within the audiences' view of the news room.

- Editorial or anchor endorsement - a positive reference - including both verbal and non-verbal forms - to a specific product or brand by one or more newsreader, reporter or anchor.

- Ad plug - a verbal or visual product or brand placement within a news story that is not essential to the story itself. 
Using this definition of publicity, the following promotional tools will automatically be excluded from this research:

- Advertising - Advertising is traditionally recognized as using mass media, speaking to a non-personal audience, being paid for, and having an identified sponsor. Within this definition the last point is most pertinent to this research as I believe that in the great majority of instances Australian commercial television in news audiences would be able to correctly identify advertising within a news bulletin. Further, advertising is typically presented as a clustered grouping making it easily distinguishable from the content of the news bulletin itself.

- Sponsorship - For the purposes of this research sponsorship will be identified, and hence excluded, by phrases such as 'sponsored by' and 'brought to you by', 'with thanks to our Sponsors' etc. This can be communicated either visually or verbally preceding or following the content within their news bulletin - that is not during a defined advertising break.

\section{RESULTS}

Across all networks for the period 29 July to 4 August 2007, 994 publicity items were recorded across 474 news items. This averages 142 items across all networks per day and equates to just over two instances of publicity (in all its forms) per news story.

As seen in Graph 1, ad plugs were by far the most frequently used type of publicity device, with a total of 715 instances across all networks. This was followed by on-set product placement, which accounted for 194 instances of publicity recorded during the sample period. Combined, general publicity, network cross promotion, proprietor cross promotion, promotion for the same news program and reporter endorsement accounted for less than ten per cent of the total instances of publicity recorded during the sample week. The least frequently used publicity device was proprietor cross promotion, of which only two instances were recorded.

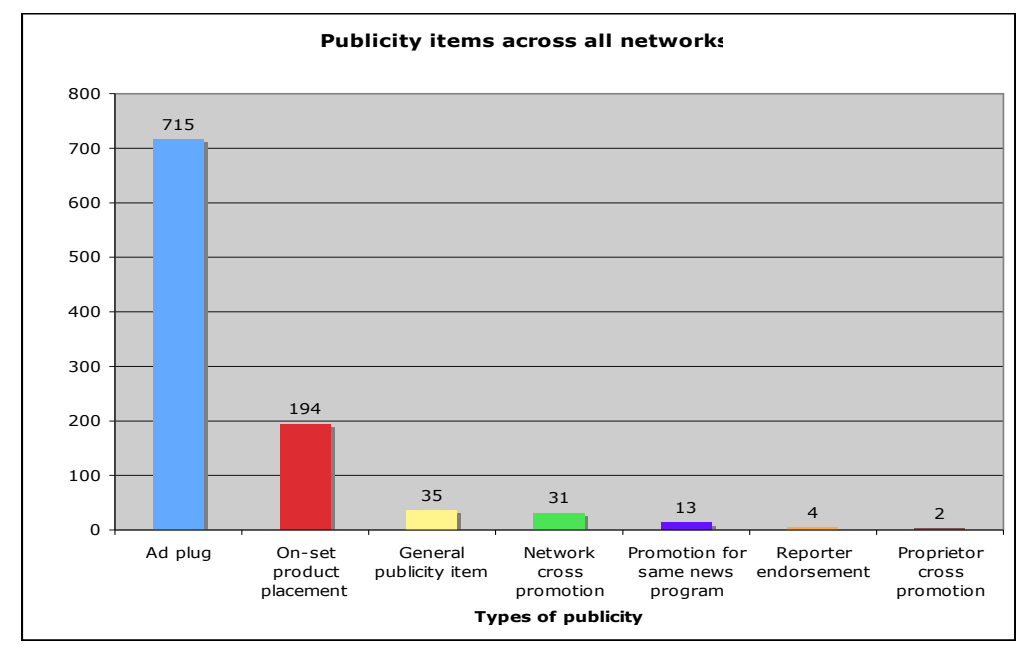

Graph 1

Only 35 news items in the sample period used general publicity - publicity in a traditional 
sense. Of these general publicity stories the vast majority, 32 of 35 , occurred in general news segments. The remaining instances were located in sports segments. The mean score for general publicity stories was 3.34. This means that there were just over three out of a maximum of ten factors that identified the story as a general publicity item. Hence, on average, publicity stories identified were fairly mild cases.

Channel Seven offered the second most promotional news bulletin during the sample period. On average per nightly bulletin, Channel Seven screened 26.43 ad plugs, 9.71 instances of on-set product placement and 2.29 instances of general publicity. As shown in Graph 2, on average audiences would have seen less than one instance of reporter endorsement, network cross promotion, proprietor cross promotion or promotion for the same news program per nightly bulletin.

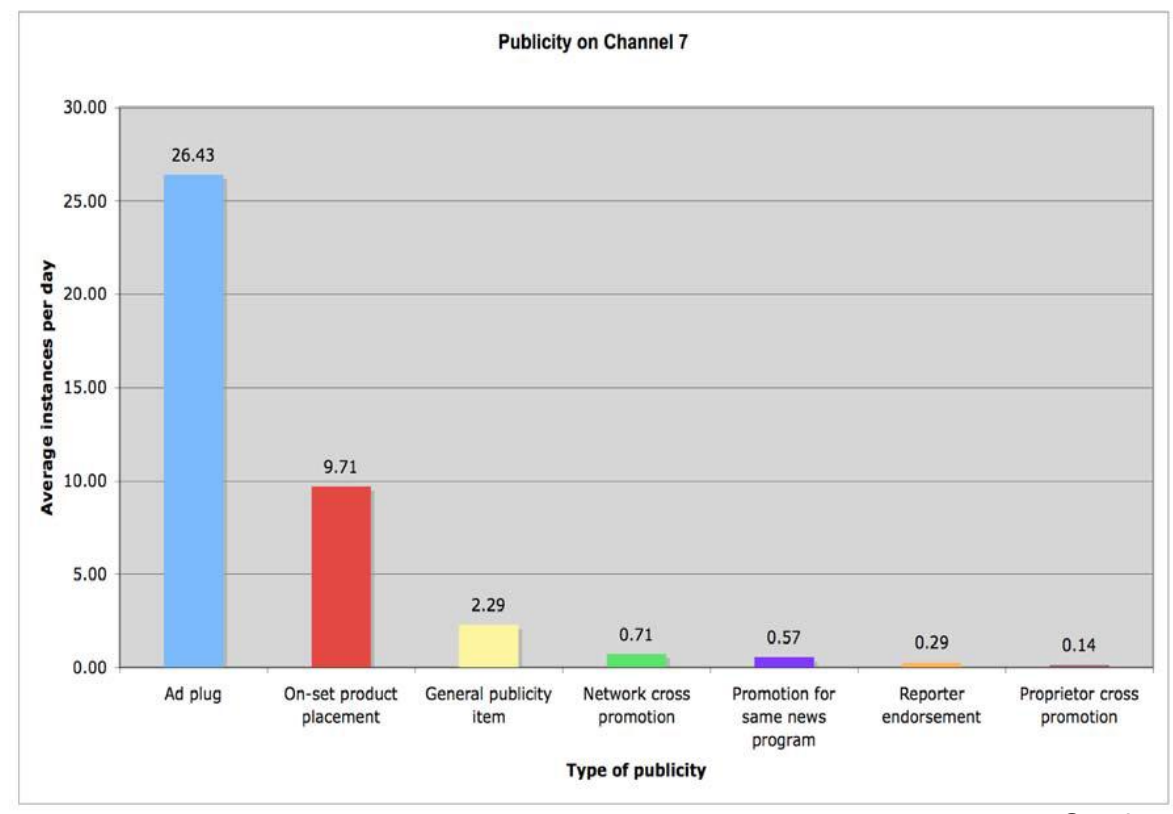

Graph 2

Channel Nine was the least promotional news program recorded during the sample period. Audiences of Channel Nine's nightly 6pm bulletin during the period 29 July to 4 August 2007 would have experienced almost one fifth less publicity than Channel Ten and an eighth less publicity than Channel Seven. While ad plugs and on-set product placement again featured prominently on this network, network cross promotion was more frequent than general publicity. On average per nightly bulletin, Channel Nine screened 28.86 ad plugs, 2.86 instances of on-set product placement, two instances of network cross promotion and 1.43 instances of general publicity. Channel Nine's results are presented in Graph 3. 


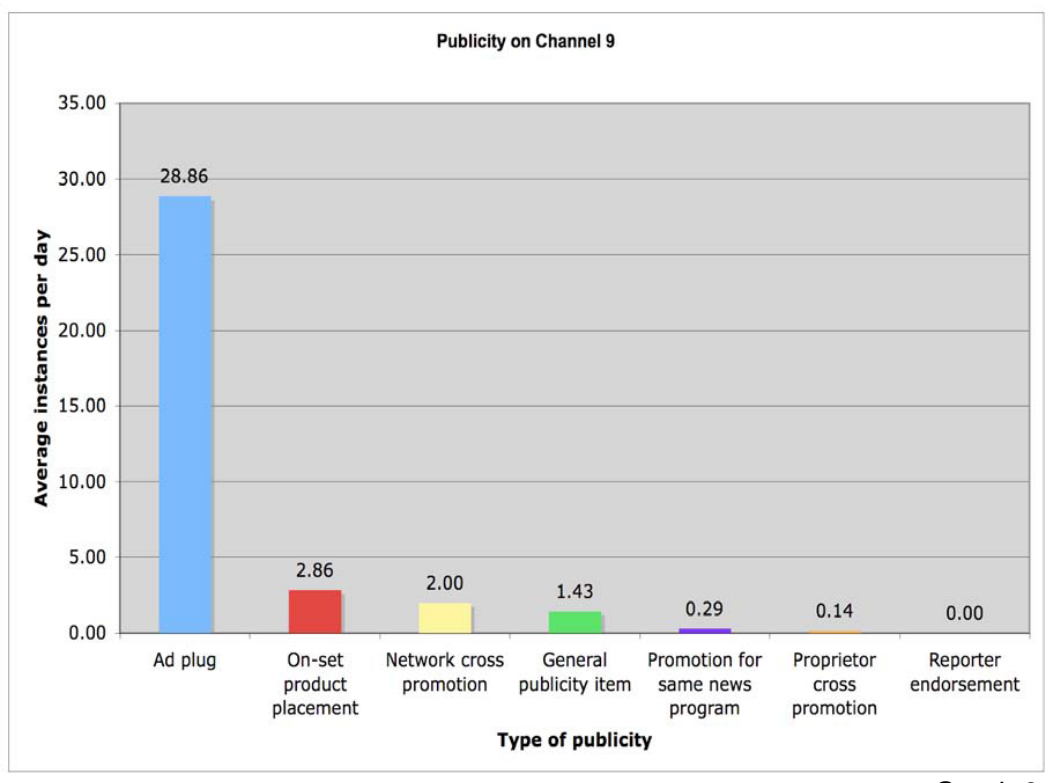

Graph 3

While on-set product placement was the second most frequently used publicity tool on both Channels Nine and Seven, Channel Nine used this tool less than one third as much as Channel Seven. This is partially accounted for by the fact that whenever Channel Seven uses an image behind the reporter in the newsroom, an LG-brand frame surrounds the image. No such on-set branding is used on Channel Nine.

Audiences of Channel Ten's 5pm or 6pm bulletins during the period 29 July to 4 August 2007 would have experienced more publicity material than on Channels Seven or Nine. On average, per nightly bulletin, Channel Ten screened 46.86 ad plugs, 15.14 instances of on-set product placement, 1.71 instances of network cross promotion, 1.29 instances of general publicity and one instance of promotion for the same news program. A total of 328 ad plugs across 85 stories were recorded on Channel Ten during the sample period. This averages to 3.86 ad plugs per story that used them, the highest instance across all three channels observed. Ad plugs on Channel Ten were most frequently seen during the sports segment. Channel Ten's results are presented in Graph 4. 


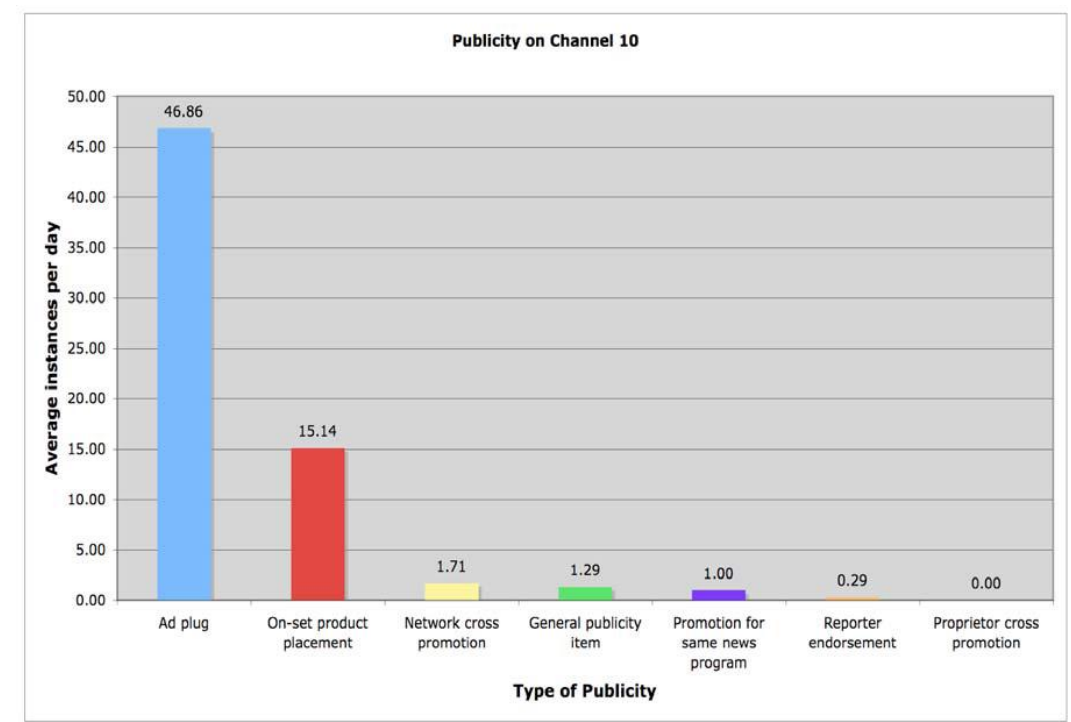

Graph 4

Promotion for the same news program, proprietor cross promotion, and reporter endorsement were comparatively infrequent during the Channel Ten bulletins analysed. Audiences were exposed on average to less than one of these publicity methods per day. No instances of proprietor cross promotion were recorded on Channel Ten during the sample week.

\section{DISCUSSION}

Content analysis research revealed, on average, just over two instances of publicity per news story. This highlights that the role of news, at least in part, is to act as a vehicle for delivering promotional messages. Under a traditional understanding the media provide citizens with information from which they can make decisions and this forms a critical part of democracy. So while news laden with publicity may be more interesting, more entertaining, or easier to watch it may not be presenting the information most relevant to the democratic process. In essence lowering the quality of information the media provides through the news is detrimental to democracy (Wood et al., 2004, p. 808).

While not all publicity is driven by profit-oriented motives, a significant part of it is. It promotes a consumer agenda by acting as a means for profit-seeking organizations to promote their brand, product or service. Publicity adopts and exploits the conventions of genuine news items to promote a product brand or service. In doing so, 'commercial content takes the place of more valuable news being communicated' (Erjavec, p. 573). As Balasubramanian points out that 'audiences tend to perceive the media as the legitimate source of any feature brand-related story' (p. 29), so they're likely to believe that what they see is genuine news. As noted earlier, television news with a strong emphasis on commercially-oriented items may cultivate materialist values, leading viewers to judge consumer behaviour as more important than social or political engagement (Wood et al., 2004, p. 808). 
At this stage two related forms of promotion should be considered: their misuse and their consequential impact on society. In the first instance, researcher Sut Jhally takes a critical stance towards the increasing prevalence of advertising in Western society. Jhally argues that 'advertising has become so prevalent that Western culture has simply become an attachment 'to the system of consumption and production' (Jhally, 1998). Jhally's argument complements Habermas's belief that the significant growth in market economics and 'culture consumption' has contributed to the decline in the public sphere (1989, p. 144).

The second example to consider is the 'cash for comment' affair. Media watchdog and ABC television program MediaWatch revealed that two of the country's most prominent radio personalities were being paid to give favourable editorial coverage to sponsors without disclosing this arrangement to their audience (ABA cash for comment enquiry,1999). The ensuing public outrage and enquiry highlighted an intolerance for promotion passed off as editorial content, even when the broadcasters claim they are entertainers, not journalists (ABA cash for comment enquiry, 1999).

These examples provide insight into society's possible reaction if the prevalence of publicity in news, as highlighted by the results of this research into Australian commercial television news, continues to grow.

In viewing publicity are audiences viewing something that is, at least in part, different to what they believe but these messages are delivered in such a way that audiences may not even realize the discrepancy. But if the 'cash for comment' example is anything to go by, the success of public relations practitioners in adopting news formats for promotional ends may end up being their downfall. From this example it is clear that Australian broadcast audiences do not like to be promoted to unless they are aware of it at the time.

The amount of publicity identified within news bulletins raises a second point - the relative ease with which publicity can be identified once the observer is educated on what to look for. Definitions of public relations point to a highly-sophisticated discipline including 'research to understand issues and public attitudes which have an impact on an organization; planning and implementing communication activities to effect change; and evaluating outcomes' (About us, 2008). Further, public relations is often combined with other promotional tools and techniques to maximize the effectiveness of a promoter's message. Would the average television news viewer correctly understand the different types of promotion and publicity, let alone accurately distinguish them from each other?

This research highlights that publicity is extremely sophisticated at being able to adopt 'conventions, formats and formulas' used to select and present events (Windschuttle, 1981, p. 94). Public relations practitioners know how television works and know how to manipulate television news conventions to their advantage. Video news releases exploit the fact that television audiences trust television news broadcasts, in part, because they believe they can 'see' events for themselves (Henningham, 1988, p. 1). Would the average television news viewer realize that sometimes the content of news bulletins is not collected and produced by the network itself? Would they realize the amount of skill and work involved in crafting a message to ensure it, or at least part of it, is aired in a news bulletin?

This leads us to the final point and a recurring theme within the above discussion: power and power imbalance. Knowledge of news formats and conventions is exploited by publicists and promoters who use this knowledge to their advantage and rely on an audience's lack of 
knowledge in this area to maximise the effectiveness of their messages. In addition, commercial television broadcasters have significant resources which they can dedicate towards understanding their audiences wants and needs. By contrast the average audience member's capacity to research or compare broadcasters' interests, motivations, or differences in news quality is limited.

A dual role of news - to inform and to act as a promotional vehicle - raises important issues regarding impartiality. Traditionally, news takes the role of an 'impartial observer' (Goldman and Rajagopal, 1991, p. 9). But if news also acts as a promotional vehicle then by definition it's purpose has changed and consequently it would be both very difficult and unbeneficial for it to remain impartial. This bias could then be used to dual effect, not only presenting a positive view of products and services for promoters, but enabling the media to present a view of the world that supports their interests.

While this study did not focus on the impact of publicity on audience attitudes or behaviour one simple question can be asked: if publicity in all its variations did not have at least a mildly positive impact, then why is the public relations industry growing so rapidly and why is it becoming a 'stronger presence among news reports'? (Marshall \& Kingsbury, 1996, p. 128).

All in all this research points to a situation of dissonance whereby traditional definitions, and models of television news production, do not adequately allow for profit motives of commercial television networks. Put simply, there is a gap between the traditional role of news and what audiences are getting. As McManus points out, 'no comprehensive model of news production has included the concept of markets' (1994, p. 21). Commercial television networks make no secret of the fact that they are businesses, operating to maximise profits for the benefit of their shareholders, yet traditional models of news make no allowance for this reality. If the current situation continues unchecked there are potentially serious negative consequences for democracy.

\section{CONCLUSION}

The amount of publicity in commercial television news bulletins is significant. So much so that it appears that commercial television news in Australian today has a dual role: to act as a promotional vehicle and to inform audiences. Traditional news models do not adequately cater for, or explain, this dual role. Related examples highlight the potential for consumer motives to erode democratic principles if left unchecked. Both television news consumers and producers should be educated to this situation, and a solution derived that fairly balances consumer and democratic ends. 


\section{APPENDIX A}

Sample codification sheet

Item headline/ subject:

\begin{tabular}{|c|c|c|c|c|c|c|}
\hline Date & Time & Network & Type of publicity item & $\begin{array}{l}\text { Duration of item } \\
\text { (secs) }\end{array}$ & News segment & Location in news bulletin \\
\hline & & & $\begin{array}{l}\text { General publicity item } \\
\text { diagnostic } \\
\text { sheet over) }\end{array}$ & & $\begin{array}{l}\text { General news } \\
\text { Sport } \\
\text { Weather }\end{array}$ & $\begin{array}{l}\text { Start (first and second item) } \\
\text { Middle } \\
\text { End (last item) }\end{array}$ \\
\hline & & & Network cross promotion & & $\begin{array}{l}\text { General news } \\
\text { Sport } \\
\text { Weather }\end{array}$ & $\begin{array}{l}\text { Start (first and second item) } \\
\text { Middle } \\
\text { End (last item) }\end{array}$ \\
\hline & & & Proprietor cross promotion & & $\begin{array}{l}\text { General news } \\
\text { Sport } \\
\text { Weather }\end{array}$ & $\begin{array}{l}\text { Start (first and second item) } \\
\text { Middle } \\
\text { End (last item) }\end{array}$ \\
\hline & & & $\begin{array}{l}\text { Promotion for the same news } \\
\text { program }\end{array}$ & & $\begin{array}{l}\text { General news } \\
\text { Sport } \\
\text { Weather } \\
\end{array}$ & $\begin{array}{l}\text { Start (first and second item) } \\
\text { Middle } \\
\text { End (last item) }\end{array}$ \\
\hline & & & On-set product placement & & $\begin{array}{l}\text { General news } \\
\text { Sport } \\
\text { Weather }\end{array}$ & $\begin{array}{l}\text { Start (first and second item) } \\
\text { Middle } \\
\text { End (last item) }\end{array}$ \\
\hline & & & Editorial/anchor endorsement & & $\begin{array}{l}\text { General news } \\
\text { Sport } \\
\text { Weather }\end{array}$ & $\begin{array}{l}\text { Start (first and second item) } \\
\text { Middle } \\
\text { End (last item) }\end{array}$ \\
\hline & & & Ad plug & & $\begin{array}{l}\text { General news } \\
\text { Sport } \\
\text { Weather }\end{array}$ & $\begin{array}{l}\text { Start (first and second item) } \\
\text { Middle } \\
\text { End (last item) }\end{array}$ \\
\hline
\end{tabular}

Notes: 


\section{PUBLICITY DIAGNOSTIC}

$\square$ Overtly positive in nature

$\square$ Positive headline

Categorical claim, praising the organisation, its product or service

$\square$ Reports the promotional activities and characteristics of the subject discussed.

$\square$ Lists promotional characteristics or activities of the organisation, its product or service.

$\square$ Story contains reference to one or more of the following:

$\square$ New or improved products or services

$\square$ Major contracts

$\square$ Reports on success in business

$\square$ Competitions; sponsorships

ㄱ Important visitors to factories

$\square$ Orders of new equipment or purchase of new premises

$\square$ Production milestones

$\square$ Not important to a wide audience, but rather to a limited number of individuals and organisation, and above all to the subject in question.

$\square$ Covers one organisation (product or service) or more than one organisation within the same interest group. The story presents one the positive characteristics or activities and not controversial or negative information.

$\square$ Story lacks a multiplicity of sources and contains no sources that contradict the original source.

$\square$ Story uses promotional vocabulary such as

$\square$ Positive words that shows the subject in a favourable light.

$\square$ Large number of synonyms

$\square$ Repetition of positive adjectives such as:

$\square$ Successful

$\square$ Best

$\square$ Biggest

$\square$ Important

$\square$ High-quality

$\square$ New

$\square$ Interesting

$\square$ Excellent

$\square$ Best known

$\square$ Wide range

口 First

$\square$ Especially advantageous

$\square$ Success

ㅁ Quality

$\square$ Fast-growing

․ Most interesting

$\square$ Busiest

$\square$ Best equipped

$\square$ Appealing

$\square$ Overall quality

$\square$ Good

$\square$ Other

$\square$ Name of the organisation is repeated throughout the headline, introduction and body.

$\square$ Lexical items which connote only positive meaning about the organisation

$\square$ Listing and repeating only positive characteristics of the organisation, its product or service.

$\square$ Main verbs refer to positive activities. 


\section{REFERENCES}

ABC. (2007) ABC Editorial Policies. Available at:

http://www.abc.net.au/corp/pubs/documents/newscaff.pdf. [Accessed: 25 May 2008].

ABC. (2005) ABC News and Current Affairs - Accuracy and Impartiality. Available at: http://www.abc.net.au/corp/pubs/documents/newscaff.pdf. [Accessed: 25 May 2008].

ABC. (n.d) All about the Australian Broadcasting Corporation. Available at: http://www.abc.net.au/corp/pubs/documents/ABC_Brochure_2003.pdf. [Accessed: 25 May 2008].

Balasubramanian, S. (1994) 'Beyond advertising and publicity: hybrid messages and public policy Issues'. Journal of Advertising, 23/4), 29-46.

Bernays, E.(1955) ed. The Engineering of Consent. Norman, Oklahoma: University of Oklahoma.

Brants, K. (1998) 'Who's Afraid of Infotainment?' European Journal of Communication 13/3, 315335.

Connell, R. W. (1977) Ruling Class, Ruling Culture: Studies of Conflict, Power and Hegemony in Australian Life. New York: Cambridge University Press.

Cottle, S. (2003) News, Public Relations and Power. London: Sage Publications.

Dahlgren. P. (1995) Television and the Public Sphere: Citizenship, Democracy and the Media. London: Sage Publications.

Davis, A. (2000) 'Public Relations, News Production and Changing Patterns of Source Access in the British National Media. Media'. Culture \& Society, 22/1, 39-59.

Day. M. (2006) 'Journalism's shaky future'. The Australian [internet edition]. August 31. Available at: http://www.theaustralian.news.com.au/story/0,20867,20307134-7582,00.html. [Accessed: 15 September 2006].

Erjavec, K. (2005) 'Beyond Advertising and Journalism: Hybrid Promotional News Discourse'. Discourse \& Soceity, 15/5, 553-578.

Gans, H. J. (1979) Deciding What's News: A Study of CBS Evening News, NBC Nightly News, Newsweek, and Time. New York: Vintage Books.

Gans, H. J. (2003) Democracy and the News. Oxford: Oxford University Press.

Goldman, R. \& Rajagopol, A. (1991) Mapping Hegemony: Television Coverage of Industrial Conflict. Norwood, New Jersey: Ablex Publishing Corp.

Google. Definitions of Publicity on the Web (n.d.) Available at: http://www.google.com.au/search?hl=en\&q=define\%3Apublicity\&meta. [Accessed: 21 October 2007].

Griffin, E. A. (2003) First Look at Communication Theory (5th ed.). Boston: McGraw-Hill.

Habermas, J. (1989) The Structural Transformation of the Public Sphere: An Inquiry into a 
Category of Bourgeois Society. Cambridge: Polity Press.

Harris, T. L. (1998) Value-added Public Relations: The Secret Weapon of Integrated Marketing. Lincolnwood, Chicago: NTC Business Books.

Harris. T. L. \& Whalen, P. T. (2006) The Marketer's Guide to Public Relations in the 21st Century. Mason, Ohio: Thomson.

Henningham, J. (1988) Looking at Television News. Melbourne: Longman Cheshire.

Hudson, M. (1994) The Media Game: An Insider's Guide to Powerful Publicity. Melbourne: Longman Professional.

Jhally, S. (1998).Advertising and the End of the World [video recording]. Northampton, Massachusetts: Media Education Foundation.

Langer, J. (1998) Tabloid Television: Popular Journalism and the 'Other News'. London: Routledge.

Marshall, I. \& Kingsbury, D. (1996) Media Realities: The News Media and Power in Australian Society. South Melbourne: Longman.

McKee, A. (2005) The Public Sphere: An Introduction. Port Melbourne, Victoria: Cambridge University Press.

McManus, J. H. (1992) 'What kind of Commodity is News?' Communication Research, 19/6, 787805.

McManus, J. H. (1994) Market-driven Journalism: Let the Citizen Beware? Thousand Oaks, Califormia: Sage Publications.

Minogue, K. R. (1997). The Silencing of Society: The True Cost of the Lust for News. London: Social Affairs Unit.

Network Ten. (n.d). 'The Early News'. Available at: http://www.tencorporate.com.au/library/documents/TheEarlyNews2April2007.pdf. [Accessed: 15 June 2007].

Palmer, J. (2000) Spinning into Control: News Values and Source Strategies. London: Leicester University Press.

Plasser, F. (2005) 'From Hard to Soft News Standards: How Political Journalists in Different Media Systems Evaluate the Shifting Quality of News'. Harvard International Journal of Press/Politics, $10 / 2,47-68$

PM. (1999) 'ABA Cash for Comment Inquiry'. 2 December. Available at: http://www.abc.net.au/pm/stories/s43229.htm. [Accessed: 14 June 2008].

Public Relations Institute of Australia. (2008) 'About us'. 30 May. Available at: http://www.pria.com.au/aboutus/cid/106/parent/1/t/aboutus/. [Accessed: 17 June 2008].

Robertson, S. (2006) 'Sully Battles the Ratings Beast. B\&T Weekly. December 8. p. 20. 
Rosenstiel, T., Gottlieb, C., Brady, L. A. \& Rosenheim, D. (2000) 'Time of Peril for TV News'. Columbia Journalism Review, 39/4, 84-90.

Samsup, J. (2003) 'The Portrayal of Public Relations in the News Media'. Mass Communication \& Society, 6/4, 397.

Sommerville, J. (1999) How the News Makes Us Dumb: The Death of Wisdom in an Information Society. Downers Grove, Illinois: Intervarsity Press.

Tiffen, R. (1989) News and Power. Sydney: Allen \& Unwin.

Wasburn, P. C. (1995) 'Democracy and Media Ownership: A Comparison of Commercial, Public and Government Broadcast News'. Media, Culture \& Society, 17/4, 647-676.

Winschuttle, K. \& Elliott, E. (1981) Fixing the News: Critical Perspectives on the Australian Media. North Ryde, New South Wales: Cassell Australia.

Wood, M., Nelson, M., Cho, J. \& Yaros, R. (2004) 'Tonight's Top Story: Commercial Content in Television News'. Journalism and Mass Communication Quarterly, 81/4, 807-822. 